Ristekdik (Jurnal Bimbingan dan Konseling)

Vol.6,No.2, 2021, hlm.251-258

DOI: http://dx.doi.org/10.31604/ristekdik.2021.v6i2.251-258

ISSN 2541-206X (online)

ISSN 2527-4244 (cetak)

\title{
STUDI KASUS DINAMIKA PSIKOLOGIS PENDERITA DEPRESI MAYOR DENGAN RIWAYAT PENGALAMAN KORBAN KEKERASAN OLEH ORANG TUA
}

\author{
Nur Ulfi Lutfiyah \\ Magister Psikologi Profesi Fakultas Psikologi Universitas Surabaya \\ nufi.ulfi@gmail.com
}

\begin{abstract}
Major depression is identified as a psychological disorder associated with mood disorders. There are many interrelated factors that give rise to major depressive disorder including violence by parents on children. The purpose of this study was to determine the psychological dynamics of patients with major depression with a history of victims of sexual violence. The study participants were 23-year-old women who had major depression. The approach used in this study is qualitative with a case study method. The examination was carried out using non-test methods (observation and interviews) and several psychological tests. poor parent-child relationships, as well as violence by parents that made participants vulnerable since childhood.
\end{abstract}

Keywords: Major depression, violence by parents

\begin{abstract}
Abstrak: Depresi mayor diidentifikasikan sebagai gangguan psikologis yang berkaitan gangguan suasana hati. Terdapat banyak faktor yang saling berkaitan sehingga memunculkan gangguan depresi mayor termasuk kekerasan oleh orangtua pada anak. Tujuan dari penelitian ini adalah mengetahui dinamika psikologis penderita depresi mayor dengan riwayat korban kekerasan seksual. Partisipan penelitian adalah perempuan 23 tahun yang mengalami depresi mayor. Pendekatan yang digunakan dalam penelitian ini adalah kualitatif dengan metode studi kasus.Pemeriksaan dilakukan menggunakan metode non tes (observasi dan wawancara) dan beberapa tes psikologi.Berdasarkan hasil pemeriksaan diketahui bahwadepresi mayor yang partisipan alamimerupakan hasil dari keterkaitan berbagai faktor seperti genetik, pola asuh, kualitas relasi antara orangtua dan anak yang buruk, serta kekerasan oleh orangtua yang menyebabkan partisipan rentan sejak kecil.
\end{abstract}

Kata kunci: Depresi mayor, kekerasan oleh orang tua

\section{PENDAHULUAN}

Depresi termasuk dalam gangguan suasana hati yang ditandai dengan adanya perasaan sedih teramat sangat, perasaan bersalah, merasa tidak berharga (low selfesteem), menunjukkan perilaku menarik diri dari lingkungan,memiliki kesulitan tidur, gairah seksual dan nafsu makan yang menurun, serta kehilangan minat terhadap aktivitas yang biasa dilakukan sehari-hari (Davidson, Neale, \& Kring, 2014).Menurut DSM V terdapat beberapa gejala depresi antara lain:

a. Memiliki 5 atau lebih dari gejala berikut dan sudah dialami selama 2 minggu berturutturut. Setidaknya terdapat satu dari gejala berikut yang mewakili perubahan sebelumnya; (1) suasana hati tertekan atau 
(2) menjadi tidak berminat atau hilang kesenangan.

1. Suasana hati tertekan yang dialami hampir sepanjang hari dan setiap hari.

2. Minat atau kesenangan yang menurun dalam semua atau sebagian besar aktivitas yang dirasakan hampir setiap hari.

3. Mengalami penurunan berat badan yang signifikan meskipun tidak berdiet atau penambahan berat badan. Gejala ini dapat juga ditandai dengan nafsu makan yang menurun atau naik.

4. Insomnia atau hipersomnia hampir setiap hari.

5. Agitasi atau retardasi psikomotor hampir setiap hari.

6. Merasa kehilangan energi atau rasa lelah hampir setiap hari.

7. Adanya perasaan tidak berharga, perasaan tidak pantas, atau muncul rasa bersalah yang berlebihan hampir setiap hari

8. Kehilangan kemampuan berpikir atau konsentrasi yang terjadi hampir setiap hari, baik itu secara subjektif maupun hasil pengamatan orang lain.

9. Munculnya pikiran tentang kematian secara berulang, keinginan bunuh diri tanpa disertai perencanaan (ide bunuh diri), memiliki rencana untuk bunuh diri, atau melakukan percobaan bunuh diri.

b. Gejala tersebut menyebabkan adanya gangguan fungsi yang signifikan secara klinis baik dibidang sosial, pekerjaan, atau fungsi penting lainnya.

c. Episode tersebut tidak disebabkan oleh efek fisiologis suatu zat atau kondisi medis lainnya.

d. Terjadinya episode depresi mayor tidak lebih baik dijelaskan oleh gangguan skizoafektif, skizofrenia, gangguan skizofreniformis, gangguan delusi, atau spektrum skizofrenia spesifik dan tidak spesifik dan gangguan psikotik lainnya.

e. Tidak ditemukan adanya episode manik atau episode hipomanik.

Data dari Institute for Health Metrics and Evaluation (IHME) (2107) mengatakan bahwa selama tiga dekade depresi menjadi penyakit mental nomor satu yang banyak diderita dibanding penyakit mental lainnya. Dalam Riset Kesehatan Dasar (Riskesdas) tahun 2018, depresi ditemukan sejak rentang usia 15-24 tahun, yaitu sebanyak 6,2\%. Gejala depresi akan semakin meningkat seiring dengan peningkatan usia dengan prevalensi $6,5 \%$ pada usia 55-64 tahun, 8,0\% pada usia 65-74 tahun, dan $8,9 \%$ pada usia diatas 75 tahun.

Penyebab depresi tidak dapat ditentukan oleh satu sebab. Hal ini dikarenakan penyebab depresi merupakan multifaktoiar. Artinya, berbagai macam faktor dapat menyebabkan depresi misalnya faktor genetik, hormonal, bologis, faktor sosial-budaya, maupun faktor internal dalam keluarga (Bembnowska \& Josko-Ochojska, 2015).Dalam studi faktor genetik, tidak ditemukan kelainan kromosom atau adanya gen tunggal yang dapat 
menyebabkan depresi. Namun, interaksi dari berbagai gen dapat memengaruhi produksi serotonin dan hormon tiroid sehingga menyebabkan seseorang lebih rentan terkena depresi (Machdi, 2019). Penelitian juga menyebutkan bahwa seseorang yang kerabat tingkat pertamanya mengalami depresi, 1,5 hingga 3 kali lebih rentan mengalami depresi.

Penurunan produksi neurotransmitter dalam otak juga dapat menyebabkan gejala depresi. Hal ini dikarenakan kurangnya produksi neurotransmitter diduga dapat memunculkan pikiran dan tindakan bunuh diri. Kurangnya produksi serotonin juga turut berpengaruh terhadap munculnya gejala depresi. Selain itu, adanya permasalahan dalam keluarga, pengalaman traumatis, adanya tekanan dari lingkungan sosial, serta kualitas hubungan atau relasi yang buruk antara orang tua dan anak juga dapat menyebabkan gangguan mental termasuk depresi (Bembnowska \& JoskoOchojska, 2015).

Seperti yang telah disebutkan, faktor sosial terutama keluarga dapat berpengaruh terhadap munculnya gangguan mental termasuk depresi. Beberapa penelitian menyebutkan bahwa anak-anak yang memiliki riwayat kekerasan dalam rumah tangga (KDRT), serta anak-anak yang dilecehkan secara fisik oleh orang tuamelaporkan adanya gejala depresi lebih banyak dibandingkan dengan anak-anak yang tidak mengalaminya. Hal ini dapat terjadi karena mereka merasa sedih, tidak diinginkan, dan kurang sehat dibanding teman sebayanya yang lain (Sternberg dkk, 1993). Hal serupa juga disebutkan oleh Santrock (2012) bahwa kekerasan yang dilakukan orang tua dapat menimbulkan regulasi emosi yang buruk, masalah kelekatan, hingga munculnya gejala depresi.

Krug et, al (Kurniasari, 2019) menyebutkan terdapat empat tipe kekerasan yaitu: (1) kekerasan fisik yang berarti tindakan yang dilakukan oleh orangtua atau pihak yang memiliki kekuasaan dan menimbulkan kerugian fisik pada anak. (2) kekerasan seksual yaitu tindakan yang memaksa anak untuk melakukan aktivitas hubungan seksual tanpa persetujuan atau tidak siap secara perkembangan. (3) kekerasan psikologis atau emosional, yaitu gagal atau tidak memenuhi kebutuhan tumbuh kembang anak sehingga membuatnya tidak memiliki kompetensi sesuai dengan tahap perkembangan baik secara emosi maupun sosial. Kekerasan ini dapat berupa non verbal atau non fisik seperti penolakan perawatan, sikap memusuhi, menyalahkan ataupun merendahkan. (4) Penelantaran, yaitu orangtua yang gagal untuk memenuhi kebutuhan anak baik dari segi kesehatan, pendidikan, perkembangan emosi dan kehidupan yang aman.

Berdasarkan pemaparan diatas, peneliti tertarik untuk mengetahui dinamika kepribadian penderita depresi mayor yang memiliki riwayat kekerasan fisik oleh orang tua. Selain itu, peneliti juga ingin mengetahui faktor yang memengaruhi munculnya gejala depresi klinis yang dialami oleh partisipan. 


\section{METODE}

Penelitian ini menggunakan pendekatan kualitatif dengan metode studi kasus. Studi kasus digunakan agar peneliti dapat mengolah data secara mendalam, menangkap kompleksitas dari permasalahan, dengan melibatkan berbagai informasi yang sudah didapatkan. Partisipan penelitian diperoleh dengan menggunakan teknik purposive sampling, yaitu pengambilan sampel berdasarkan maksud dan tujuan peneliti dengan mempertimbangkan kriteria-kriteria tertentu (Raco, 2010). Partisipan dalam penelitian ini merupakan seorang perempuan yang berusia 24 tahun yang diduga mengalamimajor depressive disroder atau depresi mayor. Berikut merupakan identitas partisipan:

Tabel 1. Identitas partisipan

\begin{tabular}{|c|c|}
\hline Nama & $\begin{array}{l}\text { Bunga } \\
\text { samaran) }\end{array}$ \\
\hline Jenis Kelamin & Perempuan \\
\hline $\begin{array}{l}\text { Tempat } \\
\text { Lahir }\end{array}$ & $\begin{array}{l}\text { Malang, } 24 \text { Desember } \\
1997\end{array}$ \\
\hline Alamat & Pakisaji Malang \\
\hline Pendidikan & S1 (semester 11) \\
\hline Suku Bangsa & Jawa \\
\hline $\begin{array}{l}\text { Latar } \\
\text { Budaya }\end{array}$ & Jawa \\
\hline Agama & Islam \\
\hline Urutan Kelahiran & $\begin{array}{l}\text { Anak ke-2 dari } 3 \\
\text { bersaudara }\end{array}$ \\
\hline
\end{tabular}

Peneliti menggunakan beberapa metode untuk mengungkap dinamika psikologis Bunga antara lain; 1) wawancara untuk menggali informasi terkait kehidupan Bunga, pengalaman masa lalu, maupun relasi di lingkungan yang berkaitan dengan gangguan psikologis yang dialami; 2) observasi dilakukan untuk mengamati perilaku partisipan selama pemeriksaan; 3) tes psikologi yang meliputi tes grafis, thematic apperception test (TAT), dan beck depression inventory (BDI), serta checklist diagnosa depresi mayor berdasarkan DSM-V (2013).

\section{HASIL PENELITIAN}

Hasil pemeriksaan menununjukkan bahwa Bunga memenuhi kriteria depresi mayor yang tertera di DSM-V (2013).Berikut merupakan sajian tabel diagnosa berdasarkan hasil pemeriksaan.

Berdasarkan hasil wawancara dan observasi, Bunga lahir dari keluarga yang tidak harmonis. Kedua orang tuanya sering bertengkar dan memiliki kualitas relasi yang buruk dengan Bunga. Ayah Bunga merupakan sosok yang kasar, keras, dan otoriter. Sedangkan ibu Bunga merupakan sosok yang lemah, tidak punya kuasa, dan cenderung mengalah. Perbedaan antara sifat ayah dan ibu membuat pola asuh yang diterapkan keduanya pun berbeda. Ayah Bunga sangat otoriter dan tidak memberi toleransi kesalahan. Ketika Bunga tidak bisa memenuhi tuntutan ayahnya atau melakukan kesalahan, maka ayahnya akan menghukumnya dengan melakukan kekerasan fisik, psikis, dan verbal. Ayahnya juga suka membandingkan Bunga dengan kakaknya, menganggap Bunga tidak lebih mampu dari kakaknya yang pintar.Sedangkan ibunya cenderung mengabaikan dan tidak dapat memberikan perlindungan kepada Bunga. 
Selain mengalami kekerasan fisik dan verbal dari ayahnya, Bunga juga mengalami kekerasan fisik dan verbal dari kakaknya. Ia sering dipukul dan menjadi pelampiasan dari kemarahan kakaknya.

Adanya perbandingan dan tidak adanya apresiasi dari ayah membuat Bunga memiliki persepsi bahwa yang ia lakukan selalu salah dan kurang memuaskan. Hal tersebut juga membuat Bunga menjadi kurang percaya diri dan memiliki harga diri yang rendah kekerasan tanpa pembelaan dari pihak signifikan juga membuat Bunga menganggap keluarganya bukanlah tempat yang aman. Kondisi tersebut semakin diperparah dengan ayahnya yang selingkuh dan meninggalkan keluarga, serta ibunya yang menyusul ayahnya. Kondisi ini membuat Bunga dan saudara-saudaranya ditempatkan di pondok pesantren secara tibatiba. Peristiwa terebut membuat Bunga merasa tertolak dan dibuang.

Satu tahun setelah Bunga di pondok pesantren, Bunga mulai menunjukkan gangguan psikologis, yaitu melakukan selfharm untuk menyalurkan emosi negatif. Sedangan gejala depresi muncul pertama kali tiga tahun setelahnya, ketika usianya 17 tahun. Hal tersebut dipicu karena pacarnya tidak bisa dihubungi dan menghilang tanpa kabar selama berbulan-bulan. Disaat yang bersamaan, kedua orang tua bercerai. Dua peristiwa tersebut membuat Bunga kembali merasa tertolak oleh lingkungan, merasa tidak disayang, dan tidak dipedulikan.
Sejak pertama kali gangguan muncul hingga penelitian ini dilakukan, gejala depresi yang dialami Bunga dapat menguat dan kambuh ketika ia merasa ditolak oleh lingkungan dan merasa bahwa tidak ada yang menyayanginya. Kondisi ini bisa terjadi baik kepada keluarga, teman, maupun relasinya dengan lawan jenis. Munculnya gejala depresi dan stressor yang terus menerus dialami membuat gangguan yang Bunga alami semakin parah. Gejala depresi yang muncul diiringi pikiran negatif yang semakin menguat hingga mengakibatkan halusinasi suara. Bunga mendengar ada suara anak-anak, perempuan dewasa, dan laki-laki dewasa yang mengatakan bahwa ia tidak pantas hidup, tidak berguna, dan tidak ada yang menyayanginya. Suara-suara tersebut juga sering menyuruh Bunga untuk melakukan bunuh diri.

\section{PEMBAHASAN}

Permasalahan yang Bunga hadapi saat ini adalah ketidakmampuan mengelola emosi dan pikiran yang dapat memperparah kondisi depresinya. Gangguan depresi mayor yang dialami Bunga termasuk dalam kategori cukup berat. Menurut Bembnowska \& JoskoOchojska (2015), munculnya depresi mayor terjadi karena beberapa faktor yang saling berkaitan. Berdasarkan hasil pemeriksaan, hal ini juga terjadi pada Bunga. Terdapat beberapa faktor yang saling berkaitan dan memperkuat munculnya depresi mayor pada Bunga. Faktorfaktor tersebut adalah: 


\section{Faktor genetik}

Berdasarkan hasil wawancara dan observasi, Ibu Bunga sering melakukan self-harm sebagai bentuk pelampiasan emosinya. Selain itu, Ibu Bunga juga terindikasi mengalami gejala depresi. Davies (dalam Santoso, Asiah, dan Kirana, 2017), anggota keluarga tingkat pertama dari orang yang mengalami depresi berat memiliki tingkat resiko dua hingga tiga kali terkena depresi. Ibu yang menderita depresi dan kecemasan saat hamil juga dapat mewariskan depresi dan kecemasannya tersebut pada bayi yang baru lahir. Hal ini dikarenakan depresi dapat dikaitkan dengan gen yang menempati posisi pada kromosom (Bembnowska \& Josko-Ochojska, 2015). Penelitian menyebutkan bahwa tidak ditemukan adanya gen tunggal yang dapat menyebabkan depresi. Namun, interaksi antar gen dapat memengaruhi produksi serotonin dan hormon tiroid (Machdi, 2019).

2. Relasi orang tua dengan anak (parent-child relation)

Kualitas hubungan antara orang tua dan anak berpengaruh terhadap perkembangan anak selanjutnya. Vermulst, Ha, dan Engels (2007) mengatakan bahwa sifat dan kualitas pengalaman anak saat bersama keluarganya menjadi faktor penting terhadap penyesuaian sosial-emosional di masa mendatang. Kualitas hubungan yang negatif dapat menyebabkan berbagai gangguan sosial dan emosional. Sementara kualitas hubungan yang merugikan akan menyebabkan anak kurang mampu dalam membangun dan memelihara hubungan cinta yang memuaskan (Ainsworth, 1989).

Kualitas hubungan yang rendah dan merugikan juga ditemukan pada Bunga dan orang tuanya. Kedua orang tua yang sering bertengkar, kasar, dan lalai membuat kebutuhan afeksi Bunga tidak terpenuhi dan munculnya perasaan tidak dihargai, tidak layak dicintai. Hal ini sesuai dengan hasil penelitian bahwa pengasuhan yang kasar dan lalai dapat membuat anak menganggap dirinya tidak layak dicintai dan tidak tercukupinya kebutuhan emosional (Vermulst, Ha, dan Engels, 2007). Dalam beberapa penelitian menyebutkan bahwa tidak ada keterkaitan secara langsung antara rendahnya kualitas relasi orang tua dan anak dengan depresi, kecemasan, atau ketidakpuasan hidup di masa paruh baya. Namun, Menurut Bowlby (dalam Bradford dkk, 2016) kualitas hubungan antara orang tua dan anak dapat mengembangkan kecemasan dan depresi saat anak dewasa. Anak yang tidak memiliki keterikatan hubungan yang aman dengan orang tua juga akan merasa kurang mampu dalam menangani stres, tidak konsisten dalam menjalin hubungan, dan memiliki harga diri yang rendah.

\section{Pola Asuh}

Hasil penelitian menunjukkan bahwa pola asuh yang diterapkan ayah Bunga adalah otoritatif. Ayah Bunga juga tidak segan menghukum dan melakukan kekerasan. Anak dengan pengasuhan seperti ini akan memiliki kecemasan dan rasa takut yang lebih dibandingkan orang lain, memiliki perasaan 
tidak bahagia, tidak memiliki inisiatif, dan keterampilan komunikasi yang buruk Kekerasan yang dilakukan oleh orang tua juga dapat menyebabkan anak mengalami permasalahan psikologis seperti depresi, kesulitan beradaptasi, dan penyalahgunaan obat (Santrock, 2012).Penelitian juga menyebutkan bahwa anak yang mengalami kekerasan fisik oleh orangtua beresiko memiliki ide bunuh diri, serta percobaan bunuh diri di masa remaja (Sternberg dkk, 1993). Lebih lanjut, Kurniasari (2019) mengelompokkan empat dampak kekerasan antara lain:

a. Sikap permisif yang muncul karena adanya perasaan tidak berguna sehingga menjadi lebih pendiam, mengisolasi diri, dan tidak mampu menjalin relasi dengan baik dan sehat.

b. Sikap depressif yang ditandai dengan perasaan sedih, murung, dan mudah menangis meskipun dalam kondisi yang menyenangkan. Dampak lain yang terkait adalah mengalami kecemasan dan trauma terhadap hal-hal terkait figur otoritas.

c. Sikap agresif yang terbentuk karena ketidakmampuan melawan figur otoritas sehingga anak melampiaskannya dengan berperilaku negatif untuk menunjukkan bahwa ia kuat dan mampu berkuasa.

d. Sifat destruktif yang muncul sebagai akibat ketidakmampuan menyelesaikan permasalahannya sehingga melampiaskan dengan menyakiti diri sendiri hingga percobaan bunuh diri.

\section{SIMPULAN}

Berdasarkan hasil penelitian dan pembahasan, dapat disimpulkan bahwa depresi mayor yang terjadi pada partisipan terjadi karena berbagai faktor yang saling berhubungan. Adanya faktor predisposisi seperti genetik membuat partisipan lebih rentan terhadap munculnya gejala. Faktor tersebut diperkuat dengan pola asuh yang tidak tepat, kualitas relasi antara orangtua dan anak yang buruk, serta kekerasan yang dilakukan oleh orangtua menjadi faktor yang semakin memperkuat munculnya gejala. Dengan dampak psikologis yang partisipanrasakan seperti perasaan tertolak, tidak dicintai, diabaikan, serta tidak mampu dalam menjalin relasi, jika bertemu dengan situasi atau kondisi yang membuat partisipan kembali merasakan dampak tersebut dan tidak bisa menyelesaikannya, maka akan menjadi pemicu munculnya gejala depresi mayor.

Keterbatasan pada penelitian ini adalah terkait jumlah partisipan yang tunggal. Hal ini mengakibatkan tidak adanya data pembanding yang memberikan gambaran lebih luas terkait dinamika psikologis penderita depresi mayor dengan riwayat kekerasan. Oleh karena itu, perlu dilakukan penelitian lanjutan dengan menambah jumlah partisipan sehingga paparan data yang didapat lebih kaya dan beragam.

\section{DAFTAR PUSTAKA}

Ainsworth, M. D. S. (1989). Attachments Beyond Infancy. American Psychologist, 44, 709-716.

Bembnowska, Marta., Josko-Ochojska, Jadwiga. (2015). What Causes Depression in 
Adults?. Pol J Public Health. 12(2), 116120.

Bradford, Angela, B., Burningham, Kayla, L., Sandberg, Jonathan, G., Johnson, Lee, N. (2016). The Association Between The Parent-Child Relationship and Symptoms of Anxiety and Depression: The Roles Of Attachment and Perceived Spouse Attachment Behaviors. Journal of Marital and Family Therapy, 43(2), 291-307.

Davidson. G. C., Neale, J. M., Kring, A. M. (2014). Psikologi Abnormal: Edisi ke-9. Jakarta: PT Raja Grafindo.

Kementrian Kesehatan RI. (2019). Situasi Kesehatan Jiwa Di Indonesia. Jakarta: Kementrian Kesehatan RI.

Kurniasari, Alit. (2019). Dampak Kekerasan Pada Kepribadian Anak. Sosio Informa, 5(1), 15-24.

Machdi, Regis. (2019). Loving The Wounded Soul. Jakarta: PT Gramedia Pustaka Utama.

Raco, R. J. (2010). Metode Penelitian Kualitatif: Jenis, Karakteristik, dan Keunggulannya. Jakarta: PT Gramedia Widiasarana Indonesia.

Santoso, Meilanny, Budiarti., Asiah, D. H. S., Kirana, Chenia, Ilma.(2017). Bunuh Diri Dan Depresi Dalam Perspektif Pekerjaan Sosial. Prosiding Penelitian \& Pengabdian Kepada Masyarakat. 4(3), 390-447.

Santrock, J. W. (2012). Life-Span Development: 13 th edition. Jakarta: Penerbit Erlangga.

Sternberg, J. K., Lamb, E. M., Greenbaum, C., Cicchetti, D., Dawud, S., Cortes, M. R., Krispin, O., \& Lorey, F. (1993), Effect of Domestic Violence on Children's Behavior Problems and Depression. Developmental Psychology. 29(1), 44-52.

Sternberg, K. J., Lamb, M. E., Greenbaum, C., Cicchetti, D, et all. (1993). Effect of
Domestic Violence on Children's Behavior Problems and Depression. Developmental Psychology, 29(1),44-52.

Vermulst, Ad., Ha, Thao., \& Engels, R. C. M. E. (2007). Parent-Child Relationship, and Emotional Adjustment: A Birth-toMaturity Prospective Study. Development Psychology. 43(2),429-437. 